\title{
PARTISIPASI MASYARAKAT DALAM MANAJEMEN BENCANA DI KOTA SURAKARTA
}

\author{
Joko Pramono ${ }^{1 *}$, Joko Suranto ${ }^{2}$ \\ 1,2, Fakultas Ilmu Sosial dan Ilmu Politik, Universitas Slamet Riyadi \\ *)Korespondensi: masjepe69@gmail.com
}

Article Histori:

Accepted: $18 / 8 / 2020$

Review: 6/10/2020

Publish: 30/4/2021
Abstract

This study explores community participation in disaster management in Surakarta. The method in this research is descriptive qualitative with interactive data analysis. The research data is in the form of primary and secondary data which were extracted through interviews, observation and documentation. The results showed that community participation in disaster management was evident at the disaster management stage. Communities together carry out rescue, evacuation and provision of emergency posts or evacuation. The community also works together in providing all the needs of Be affected residents. Participation is not optimal in the pre-disaster and post-disaster stages. This is due to the lack of public awareness, the absence of firm sanctions and the absence of a forum for the community to work together with the government to plan and evaluate disaster activities

Keyword: Participation, Community, Disaster management

\section{PENDAHULUAN}

Indonesia termasuk negara dengan potensi kerawanan bencana alam. Data yang diperoleh dari Data Badan Penanggulangan Bencana Daerah (BNPB, 2019) menyebutkan bahwa sepanjang tahun 2018 sampai 2019 telah terjadi 3.999 bencana. Bencana yang paling sering terjadi adalah puting beliung sejumlah 1.372 kejadian, banjir sejumlah 1.064 kejadian dan tanah longsor sejumlah 829 kejadian. BNPB (2019) menyatakan daerah yang paling rawan terhadap bencana adalah Provinsi Jawa Tengah. Tercatat selama tahun 2019 ini terjadi 420 bencana alam dan terdapat kemungkinan bertambah. Provinsi Jawa Tengah menduduki tingkat tertinggi daerah yang paling banyak mengalami bencana alam, dan disusul Provinsi Jawa Barat sejumlah 263 bencana pada tahun 2019.

Kota Surakarta merupakan salah satu kota di Provinsi Jawa Tengah dengan potensi rawan bencana yang menarik diteliti. Kota ini dilewati aliran Sungai Bengawan Solo sehingga menyebabkan Kota Surakarta menjadi kota yang rawan dengan potensi bencana yang banjir disebabkan aliran dari Sungai Bengawan Solo. Data Badan Penanggulangan Bencana Daerah (BPBD) (2019) Kota Surakarta menyebutkan bahwa 25 Kelurahan dari jumlah 51 Kelurahan di Kota Surakarta dipetakan menjadi daerah rawan banjir. Ini berarti sekitar setengah dari kelurahan yang 
ada di Kota Surakarta merupakan daerah rawan banjir. Apalagi, Sungai Bengawan Solo kerap mendapat kiriman air dari kabupaten di sekitaran kota Surakarta yang dapat meningkatkan potensi bencana banjir. Sehingga penting adanya manajemen bencana di Kota Surakarta sebagai bentuk pengurangan resiko bencana yang dapat menyebabkan kerugian baik bagi pemerintah maupun masyarakat.

Kerugian yang ditimbulkan dari bencana berbentuk materiil maupun non meteriil. Dampak bencana secara meteriil adalah rusaknya sarana prasarana baik pribadi maupun sarana umum, dan hilangnya harta benda. Dampak bencana secara nonmateriil adalah banyaknya korban jiwa baik meninggal, luka-luka atau terdampak secara psikis, dampak kerusakan lingkungan dan tumbulya berbagai macam penyakit yang menyertai.

Perlu manajemen bencana yang memadai dalam upaya penanggulangan bencana. Dalam UU No 24 Tahun 2007 kita dapat memahami makna manajemen bencana sebagai proses yang dinamis, berlanjut, dan terpadu, yang dilakukan guna meningkatkan kualitas langkah sehubungan dengan observasi dan analisis terhadap bencana serta pencegahan, mitigasi, peringatan dini, penanganan darurat, kesiapsiagaan, rehabilitasi dan rekonstruksi bencana. Kegiatan manajemen bencana ini penting sebagai upaya dalam mengurangi dampak dari bencana.

Manejemen bencana idealnya mampu menarik partisipasi aktif masyarakat. Kata "partisipasi" didefinisikan oleh Ach. Wazir Ws., et al. (1999) sebagai suatu keterlibatan seseorang yang dilakukan dengan sadar pada interaksi sosial dalam situasi tertentu. Adapun Isbandi (2007) juga mencoba mengartikan "partisipasi" sebagai keterlibatan masyarakat pada proses untuk mengidentifikasi potensi dan masalah yang terdapat di dalam masyarakat, pemilihan serta pengambilan keputusan mengenai pilihan solusi yang digunakan untuk menyelesaikan masalah, pelaksanaan dalam rangka mengatasi masalah, sampai pada keterlibatan masyarakat untuk melakukan evaluasi terhadap perubahan yang terjadi. Masyarakat harus terlibat aktif mulai dari pencegahan, mitigasi, kesiapsiagaan bencana, sampai pada penanganan darurat dan rehabilitasi. Berdasakan latar belakang tersebut, penelitian ini berupaya menggali partisipasi masyarakat dalam manajemen bencana yang terjadi di Kota Surakarta. Tujuan penulisan ini adalah untuk menderskripsikan partisipasi masyarakat Surakarta dalam manajemen bencana.

\section{KAJIAN LITERATUR}

\section{Manajemen Bencana}

Manajemen bencana adalah suatu proses dinamis, berlanjut dan terpadu untuk meningkatkan kualitas langkah-langkah yang berhubungan dengan observasi dan analisis bencana serta pencegahan, mitigasi, kesiapsiagaan, peringatan dini, penanganan darurat, rehabilitasi dan rekonstruksi bencana. (UU 24/2007). Manajemen bencana menurut Nurjanah (2012) sebagai Proses dinamis tentang bekerjanya fungsifungsi manajemen bencana seperti planning, organizing, actuating, dan controling. Cara kerjanya meliputi pencegahan, mitigasi, dan kesiapsiagaan tanggap darurat dan pemulihan. Manajemen bencana adalah proses yang berkesinambungan dan terpadu dimulai dari perencanaa, pengorganisasian, koordinasi dan langkahlangkah yang perlu dilakukan antara lain: 1) Pencegahan dari bahaya atau ancaman bencana, 2) Mitigasi atau pengurangan risiko bencana terhadap berbagai bencana, keparaham dan konsekuensinya, 3) Peningkatan kapasitas, 4) Kesiapsiagaan 
terhadap berbagai macam bencana, 5) Respon cepat terhadap situasi bencan maupun bencana yang mengancam, 6) Menilai keparahan atau besarnya efek yang ditimbulkan akibat bencana, 7) Evakuasi adalah prose penyelamatan dan pemberian bantuan, dan 8) Rehabilitasi dan rekonstruksi (The DM Act, 2005),

Tujuan manajemen bencana secara umum adalah sebagai berikut: (1) Mencegah dan membatasi jumlah korban manusia serta kerusakan harta benda dan lingkungan hidup; (2) Menghilangkan kesengsaraan dan kesulitan dalam kehidupan dan penghidupan korban; (3) Mengembalikan korban bencana dari daerah penampungan/ pengungsian ke daerah asal bila memungkinkan atau merelokasi ke daerah baru yang layak huni dan aman; (4) Mengembalikan fungsi fasilitas umum utama, seperti komunikasi/ transportasi, air minum, listrik, dan telepon, termasuk mengembalikan kehidupan ekonomi dan sosial daerah yang terkena bencana; (5) Mengurangi kerusakan dan kerugian lebih lanjut; (6) Meletakkan dasar-dasar yang diperlukan guna pelaksanaan kegiatan rehabilitasi dan rekonstruksi dalam konteks pembangunan.

\section{Partisipasi Masyarakat}

Menurut Ach. Wazir Ws., et al. (1999) partisipasi bisa diartikan sebagai keterlibatan seseorang secara sadar ke dalam interaksi sosial dalam situasi tertentu. Dengan pengertian itu, seseorang bisa berpartisipasi bila ia menemukan dirinya dengan atau dalam kelompok, melalui berbagai proses berbagi dengan orang lain dalam hal nilai, tradisi, perasaan, kesetiaan, kepatuhan dan tanggungjawab bersama. Partisipasi masyarakat menurut Isbandi (2007: 27) adalah keikutsertaan masyarakat dalam proses pengidentifikasian masalah dan potensi yang ada di masyarakat, pemilihan dan pengambilan keputusan tentang alternatif solusi untuk menangani masalah, pelaksanaan upaya mengatasi masalah, dan keterlibatan masyarakat dalam proses mengevaluasi perubahan yang terjadi. Pentingnya partisipasi dikemukakan oleh Conyers (1991) pertama, partisipasi masyarakat merupakan suatu alat guna memperoleh informasi mengenai kondisi, kebutuhan, dan sikap masyarakat setempat, yang tanpa kehadirannya program pembangunan serta proyekproyek akan gagal; kedua, bahwa masyarakat akan lebih mempercayai proyek atau program pembangunan jika merasa dilibatkan dalam proses persiapan dan perencanaannya, karena mereka akan lebih mengetahui seluk-beluk proyek tersebut dan akan mempunyai rasa memiliki terhadap proyek tersebut; ketiga, bahwa merupakan suatu hak demokrasi bila masyarakat dilibatkan dalam pembangunan masyarakat mereka sendiri.

Menurut Juliantara (2002) substansi dari partisipasi adalah bekerjanya suatu sistem pemerintahan dimana tidak ada kebijakan yang diambil tanpa adanya persetujuan dari rakyat, sedangkan arah dasar yang akan dikembangkan adalah proses pemberdayaan, lebih lanjut dikatakan bahwa tujuan pengembangan partisipasi, pertama bahwa partisipasi akan memungkinkan rakyat secara mandiri (otonom) mengorganisasi diri, dan dengan demikian akan memudahkan masyarakat menghadapi situasi yang sulit, serta mampu menolak berbagai kecenderungan yang merugikan. Kedua, suatu partisipasi tidak hanya menjadi cermin konkrit peluang ekspresi aspirasi dan jalan memperjuangkannya, tetapi yang lebih penting lagi bahwa partisipasi menjadi semacam garansi bagi tidak diabaikannya kepentingan masyarakat. Ketiga, bahwa persoalan-persoalan dalam dinamika

P-JIAP: Vol. 6 (1) 2021

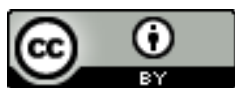


pembangunan akan dapat diatasi dengan adanya partisipasi masyarakat

\section{METODE PENELITIAN}

Penelitian ini merupakan penelitian kualitatif deskriptif. Penelitian deskriptif kualitatif merujuk pada penelitian dengan tujuan menggambarkan, meringkas berbagai kondisi, situasi maupun fenomena realitas sosial di masyarakat sebagai objek dari penelitian (Huberman,2014). Penelitian ini berupaya untuk menarik realitas ke permukaan sebagai sifat, karakter, ciri, model, maupun gambaran mengenai suatu kondisi, fenomena atau situasi tertentu (Bungin, 2007). Lokasi penelitian dilaksanakan di Kota Surakarta, lokasi ini dipilih karena Kota Surakarta adalah salah satu daerah dengan potensi rawan bencana, seperti bencana banjir. Data yang digali dalam penilitian ini adalah dalam primer dan sekunder. Data primer penelitian didapatkan secara langsung dari lokasi penelitian, yakni melalui wawancara, diskusi dan observasi. Wawancara dilakukan kepada anggota BPBD dan jug masyarakat setempat. Pemilihan informan pada wawancara dilakukan secara snow ball sampai data jenuh. Jumlah informan yang penulis dapatkan sejumlah 15 orang, baik dari masyarakat maupun dari BPBD. Adapun data sekunder didapat dari dokumen-dokumen pendukung, yakni dari informan, peristiwa dan dokumen Data yang telah diperoleh peneliti kemudian dianalisis. Analisis data dalam penelitian ini dilakukan secara terus menerus selama proses pengambilan data. Peneliti memilah dan mengkatagorikan data yang telah diperoleh sesuai dengan informasi yang dibutuhkan

\section{HASIL DAN PEMBAHASAN}

Parker dalam Wijayanto (2012) menjelaskan bahwa bencana merupakan kejadian tidak biasa yang dapat terjadi karena alam atau karena ulah manusia, yang di dalamnya merupakan imbas kesalahan teknologi yang memicu respon masyarakat, komunitas, individu atau lingkungan sehingga memberikan antusiasme yang sifatnya luas. Bencana yang paling sering terjadi adalah puting beliung sejumlah 1.372 kejadian, banjir sejumlah 1.064 kejadian dan tanah longsor sejumlah 829 kejadian. BNPB (2019) menyatakan daerah yang paling rawan terhadap bencana adalah Provinsi Jawa Tengah. Salah satu Kota di Provinsi Jawa Tengah yang juga rawan terhadap bencana adalah Kota Surakarta. Kota Surakarta rawan dikarenakan adanya aliran Sungai Bengawan Solo yang melewatinya, sehingga berpotensi terjadi bencana banjir. Kondisi ini menjadi alasan pentingnya manajemen bencana di Kota Surakarta sebagai bentuk pengurangan resiko bencana yang dapat menyebabkan kerugian baik bagi pemerintah maupun masyarakat.

Carter (1991), menjelaskan Disester management, sebagai "an applied science which seeks, by the systematic observation and analysis of disester, to improve measures relating to prevention, mitigation, preparedness, emergency response and recovery". Pendapat Carter ini dapat diejawantahkan bahwa tahapan manajemen bencana berupa: pencegahan, mitigasi, kesiapsiagaan, tanggap darurat serta pemulihan dengan pengamatan juga analisa tersistematis terhadap bencana. Kegiatan dalam manajemen bencana yang dilakukan berupa: perencanaan (planning), pengorganisasian (organizing), penggerakan (actuating), dan pengawasan (controlling). The Disaster Management (DM Act) (2005) dan National Disaster Mitigation and Prevention (NDMP) (2009) menjelaskan bahwa terdapat beberapa aspek penting dalam manajemen bencana yaitu pengurangan risiko bencana, managemen 
risiko bencana, kesiapsiagaan bencana, respon terhadap bencana, dan recovery setelah bencana. Dalam penelitian ini manajemen bencana terbagai menjadi beberapa tahap yaitu tahapan sebelum bencana, tahap penanganan bencana dan pasca bencana. Tahap sebelum bencana meliputi perencanaan, pencegahan, dan kesiapsiagaan bencana. Tahap penanganan bencana berupa penggerakan atau aktivitas yang dilakukan pada saaat bencana terjadi. Tahap pasca bencana meliputi pemulihan, dan evaluasi.

Kegiatan manajemen bencana di kota Surakarta melipatkan partisipasi aktif dari masyarakat. Isbandi (2007) menjelaskan bahwa parsipasi masyarakat, sebagai keterlibatan masyarakat pada proses untuk melakukan identifikasi masalah serta potensi dalam masyarakat, memilih dan mengambil keputusan terkait berbagai pilihan solusi yang bisa digunakan dalam menyelesaikan masalah, melaksanakan usaha dalam mengatasi masalah, dan juga keikutsertaan masyarakat pada proses evaluasi dari perubahan yang terjadi. Partisipasi masyarakat menjadi hal penting untuk dilakukan dalam manajemen bencana. Conyers (1991) menjelaskan alasannya, berupa: pertama, partisipasi masyarakat merupakan alat yang berguna untuk mendapat informasi kondisi, sikap juga kebutuhan masyarakat setempat, karena jika tidak ada hal ini, berbagai program pembangunan dan aneka proyek dapat mengalami kegagalan; kedua, bagi masyarakat kemungkinan akan percaya pelaksanaan program pembangunan atau proyek ketika meraka merasa terlibat pada proses persiapan dan perencanaan dari program tersebut, dikarenakan masyarakat dapat lebih mengetahui berbagai hal terkait proyek tersebut dan dapat menimbulkan adanya rasa bahwa masyarakat ikut mempunyai proyek tersebut; ketiga, masyarakat memiliki hak demokrasi untuk dilibatkan dalam kegiatan pembangunan masyarakat mereka sendiri.

Partisipasi masyarakat manajemen bencana meliputi beberapa tahapan sebelum bencana, tahap penanganan bencana serta pasca bencana. Tahap sebelum bencana meliputi perencanaan, pencegahan, dan kesiapsiagaan bencana. Pada tahap perencanaan. Masyarakat hendaknya berpartisipasi aktif dalam identifikasi masalah. Identifikasi masalah adalah kegiatan awal masyarakat dalam merencanakan suatu mitigasi bencana, namun hal ini keterlibatan masyarakat masih belum optimal karena belum terlihat kerjasama antara masyarakat dan pemerintah dalam hal ini BPBD untuk duduk bersama mengidentifikasi permasalahan banjir yang terjadi di Kota Surakarta. Keterlibatan masyarakat mulai terlihat pada kegiatan pencegahan, mitigasi dan kesiapsiaaan bencana.

Masyarakat dalam bentuk Satlinmas dan juga kelompok tanggap bencana berpartisipasi aktif dalam melakukan pengawasan terhadap kondisi sungai yang melewati wilayah masing-masing. Penggawasan ini dilakukan pada tingkat RT dan RW. Kegiatan ini penting dilakukan sebagai langkah awal dalam rangka deteksi dini ketika air sungai sudah mulai naik. Pengawasan tidak hanya dilakuka terhadap debit air tetapi juga terhadap perilaku masyarakat. Perilaku masyarakat yang sering membuang sampah di sungai menjadi salah satu faktor penyebab banjir yang ada di kota Suarakarta. Pengawasan terhadap perilaku masyarakat ini menjadi salah satu faktor penting terjaganya kondisi sungai, sehingga tidak terjadi penumpukan sampah yang menyebabkan banjir. Pengawasan sebagai bentuk pencegahan ini tentunya tidak mudah karena, dilapangan menemukan berbagai kendala seperti belum

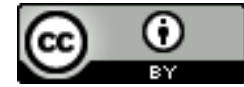


adanya kesadaran masyarakat untuk tidak membuang sampah sembarangan, seperti di sungai dan tidak adanya tindakan tegas atau sanksi terhadap masyarakat yang membuang samppah di sungai. Sebagai anggota masyarakat, Satlinmas maupun kelompok tangggap bencana tidak memiliki kekuatan hukum untuk memberikan efek jera, sehingga mereka hanya bisa memberikan peringatan saja kepada masayarakat yang tidak patuh. Hal ini berdampak pada kurang efektifnya kegiatan pencegahan bencana banjir di Kota Suarkarta.

Kesiapsiagaan masyarakat terhadap terjadinya bencana banjir juga belum menunjukkan hasil yang baik. Masyarakat belum menunjukkan sikap yang sigap ketika bencana terjadi. Hal ini diakobatkan oleh kurangnya fasilitas tanggap bencana seperti perahu dan posko untuk bencana. Beberapa wilayah telah mendapatkan perahu karet dari PMI untuk mengatasi bencana, namun kurang dilakukan perwatan tehadap fasilitas tersebut karena tidak adanya biaya. Posko-posko bencana juga tidak ditetapkan secara resmi sehinga masyarakat tidak cepat tanggap ketika terjadi bencana. Walaupun peringatan dini terhadap terjadinya bencana telah dilakukan dengan pengawasan oleh masyarakat sekitar, namun masyarakat cenderung acuh dengan peringatan yang sudah diberikan.

Berdasarkan uraian tersebut partisipasi masyarakat dalam kegiatan pra bencana di Kota Surakarta belum berjalan optimal. Kondisi ini disebabkan belum adanya keterlibatan masyarakat dalam identifikasi masalah, belum adanya kesadaran masyarakat untuk menjaga lingkungan, tidak adanya sanksi tegas bagi masyarakat yang melanggar aturan dan kurangnya kesiap-siagaan masyakat. Citizen Corps (2006) mengungkapkan bahwa faktor yang dapat berpengaruh terhadap kesiapsiagaan terhadap bencana, antara lain faktor eksternal berupa motivasi yang meliputi kebijakan, pendidikan dan latihan, serta dana berupa faktor pengetahuan, faktor sikap dan faktor keahlian. Di sisi lain, sudah terdapat partsisipasi masyarakat pada tingkat RT dan RW dalam melakukan pengawasan terhadap deteksi dini bencana.

Tahapan selanjutnya dalam manajemen bencana adalah penanganan bencana. Penanganan bencana berupa penggerakan atau aktivitas yang dilakukan pada saaat bencana terjadi. Kegiatan yang dilakukan ketika bencana terjadi mencakup kegiatan tanggap darurat untuk meringankan penderitaan sementara, dan juga untuk menanggulangi dampak yang ditimbulkan, seperti kegiatan search and rescue (SAR), penyelamatan korban serta harta benda, evakuasi, bantuan darurat dan pengungsian. Partisipasi masyarakat dalam penanganan bencana terlihat jelas dimasyarakat dengan aktifnya masyarakat membantu satu sama lain. Gotong royong merupakan proses sukarela untuk berbagi ide, melakukan pengorganisasian masyarakat, koleksi bahan, kontribusi keuangan, dan juga dalam memobilisasi tenaga pelaksana kegiatan sosial dan budaya (Bintarto,1983).

Gotong royong dapat terjadi di antara warga yang terdampak bencana dan juga dengan warga lain di luar wilayah dampak becana. Pemuda, Satlinmas dan kelompok tanggap bencana juga aktif dalam menyediakan posko dan bantuan terkait dengan kebutuhan sehari-hari warga terdampak. Partisipasi masyarakat juga terlihat dalam bentuk peggalangan bantuan yang dilakukan oleh masyarakat sekitar terdampak bencana. Tahap penanganan bencana terlihat jelas partisipasi masyarakat dalam penanganan bencana dengan 
bersama sama melakukan penyelamatan, evakuasi dan penyediaaan posko darurat atau pengungsian. Masarakat juga bergotong royong dalam menyediakan semua kebutuhan warg yan terdampak.

Tahap terakhir dalam manajemen bencana adalah pasca bencana. Kegiatan pasca bencana meliputi pemulihan dan evaluasi. Dalam kegiatan pemulihan dilakukan pemulihan terhadap trauma bencana. Pemulihan tidak hanya dilakukan secara fisik, tetapi juga meliputi psikis. Pentingnya aktifitas ini kerap dilalaikan ketika bencana telah usai. Masyarakat mengangkap bencana telah selesai sehingga tidak ada lagi upaya yang perlu dilakukan. Hal yang sama jua disampaikan oleh Mawardi (2011) yang menyatakan bahwa keterlibatan masyarakat secara aktif dalam kegiatan pasca bencana selama ini masih belum maksimal. Tahap evauasi adalah tahapan masyarakat memberi penilaian berbagai kegiatan yang sudah dilaksanakan, dan menilai kesesuaian pelaksanaan terhadap kebutuhan, sehingga diketaui jika masih ada hal yang perlu diperbaiki. Masyarakat tidak terlibat secara langsung dalam tahap evaluasi ini. Pemerintah jarang duduk bersama masyarakat atau pihak swasta dalam rangka mempersiapkan langkah-langkah atau kegiatan-kegiatan yang dianggap perlu dilakukan dalam mengevaluasi kegiatan yang telah dilakukan selama menghadapi bencana atau bagaimana memperkecil dampak bencana.

Berdasarkan uraian tersebut, partisipasi masyarakat dalam kegiatan pasca bencana sangat kurang hal ini dikarenakan kurangya dukungan dari pemeritah untuk menyediakan wadah dalam melakukan evaluasi terhadap kegiatan yang dilakukan.

Berdasarkan uraian diatas partisipasi masyarakat Kota Surakarta dalam manajemen bencana belum dilaksanakan dengan optimal. Partisipasi masyarakat dalam kegiatan pra bencana di Kota Surakarta belum berjalan optimal. Hal ini disebabkan belum adanya keterlibatan masyarakat dalam identifikasi masalah, belum adanya kesadaran masyarakat untuk menjaga lingkungan, tidak adanya sanksi tegas bagi masyarakat yang melanggar aturan dan kurangnya kesiapsiagaan masyakat. Disisi lain sudah terdapat partsisipasi masyarakat pada tingkat RT dan RW dalam melakukan pengawasan terhadap deteksi dini bencana. Partisipasi masyarakat dalam kegiatan pasca bencana sangat kurang hal ini dikarenakan kurangya dukungan dari pemeritah untuk menyediakan wadah dalam melakukan evaluasi terhadap kegiatan yang dilakukan. Partisipasi masyarakat dalam manajemen bencana terlihat jelas pada tahap penanganan bencana. Masyarakat bersamasama melakukan penyelamatan, evakuasi dan penyediaaan posko darurat atau pengungsian. Masarakat juga bergotong royong dalam menyediakan semua kebutuhan warg yan terdampak.

Partisipasi masyarakat dalam maajemen bencana sangat penting. Juliantara (2002) berpendapat bahwa substansi partisipasi dapat dipahami sebagai bekerjanya sistem pemerintahan yang tanpa kebijakan yang diambil tidak melalui persetujuan rakyat, sedangkan terkait arah dasar yang hendak dikembangkan merujuk pada proses pemberdayaan. Adapun tujuan dari pengembangan partisipasi meliputi pertama, bahwa partisipasi memungkinkan rakyat dapat secara mandiri (otonom) mengorganisasi diri, sehingga langkah ini memudahkan masyarakat untuk bisa menghadapi situasi sulit, dan mampu menolak aneka kecenderungan yang dianggap merugikan. Kedua, partisipasi tidak hanya jadi cermin konkrit dari 
peluang ekspresi aspirasi dan jalan umtuk memperjuangkannya, melainkan juga menjadi garansi bahwa kepentingan masyarakat tidak diabaikan. Ketiga, persoalan-persoalan yang berlangsung dalam dinamika pembangunan dapat diatasi melalui adanya partisipasi masyarakat.

Partisipasi masyarakat dalam manajemen bencana Kota Surakarta masih belum terlihat dalam hal perumusan identifikasi masalah serta tahap pasca bencana berupa pemulihan dan evaluasi. Kesiapsiagaan bencana juga belum dijalankan dengan optimal. Hidayati, dkk.(2006) menyatakan bahwa ada tiga stakeholder utama yang mengambil peran dalam kesiapsiagaan, yakni: (a) rumah tangga stakeholder dan juga individu, individu serta rumah tangga merupakan ujung tombak, subjek dan objek kesiapsiagaan sehingga secara langsung mempengaruhi risiko terhadap terjadinya bencana; (b) Pemerintah, dengan peran yang dimilikinya terutama dalam kondisi sosial ekonomi masyarakat, pendidikan masyarakat terkait bencana, penyediaan fasilitas, sarana dan prasarana publik yang digunakan untuk keadaan darurat; (c) Komunitas sekolah, yang bila merujuk pada literatur klasik, menunjukan bahwa partisipasi merupakan keikutsertaan masyarakat dalam perencanaan, pelaksanaan, hingga evaluasi dalam program pembangunan, tetapi dengan makna substantif yang terkandung di dalam sekuen-sekuen partisipasi berupa voice, akses dan kontrol (Juliantara, 2002).

Partisipasi masyarakat yang kurang optimal ini disebabkan oleh kurangnya kesadaran dan kurangnya fasilitas atau wadah dari pemerintah. Masyarakat di Indonesia menganggap bahwa bencana adalah suatu takdir atau kutukan dosa serta kesalahan yang diperbuat manusia, sehingga masyarakat menerima kejadian tersebut dan tidak perlu dilakukan pencegahan atau penanggulangannya (Triutomo, Widjaja, \& Amri, 2007). Minimnya partisipasi dalam masyarakat berpotensi menjadi penghambat bagi proses penangulangan dan mitigasi bencana yang dilangsungkan di daerah tersebut. Penangulangan bencana banjir bukan hanya menjadi tanggung jawab pihak pemerintah atau lembaga terkait saja, melainkan juga membutuhkan bantuan atau partisipasi masyarakat dalam rangka mewujudkan program-program pemerintah. Inilah sebabnya, manajemen bencana perlu untuk dilakukan dengan melibatkan partisipasi masyarakat, yang terutama masyarakat setempat. Absennya partisipasi masyarakat dalam mendukung program mitigasi bencana, dapat menyebabkan gagalnya program itu sendiri. Permasalahan masyarakat dalam mitigasi bencana ini menjadi hal yang kompleks untuk ditelaah. Adapun penelaahan dalam partisipasi masyarakat ini dapat berkaitan dengan keterlibatan mental dan emosional, inisiatif dan juga tentang tanggung jawab masyarakat di dalam perencanaan, pelaksanaan serta pemantauan-pamantauan di dalam mitigasi bencana. Dibutuhkan pengkajian terkait persepsi masyarakat dalam partisipasi terbatas pada pengertian, interpretasi dan juga tanggapan masyarakat terhadap mitigasi bencana banjir. Sikap masyarakat yang dikaji secara lebih mendalam juga yang terkait dengan partisipasi terbatas dari sikap masyarakat yang diproyeksikan terhadap program kesadaran lingkungan.

\section{PENUTUP}

Partisipasi masyarakat Kota Surakarta dalam manajemen bencana belum dilaksanakan dengan optimal. Partisipasi masyarakat dalam kegiatan pra bencana di 
Kota Surakarta belum berjalan optimal. Belum optimalnya partisipasi ini dikarenakan ketiadaan keterlibatan masyarakat dalam identifikasi masalah, belum adanya kesadaran masyarakat untuk menjaga lingkungan, tidak adanya sanksi tegas bagi masyarakat yang melanggar aturan dan kurangnya kesiapsiagaan masyakat. Disisi lain sudah terdapat partsisipasi masyarakat pada tingkat RT dan RW dalam melakukan pengawasan terhadap deteksi dini bencana. Partisipasi masyarakat dalam kegiatan pasca bencana sangat kurang hal ini dikarenakan kurangya dukungan dari pemeritah untuk menyediakan wadah dalam melakukan evaluasi terhadap kegiatan yang dilakukan. Partisipasi masyarakat dalam manajemen bencana terlihat jelas pada tahap penanganan bencana. Masyarakat bersamasama melakukan penyelamatan, evakuasi dan penyediaaan posko darurat atau pengungsian. Masarakat juga bergotong royong dalam menyediakan semua kebutuhan warga yang terdampak.

Berdasarkan hasil penelitian, perlu peningkatan keterlibatan dalam identifikasi masalah, dan adanya sanksi tegas bagi masyarakat yang melanggar aturan. Pemeritah perlu menyediakan wadah dalam melakukan evaluasi terhadap kegiatan manajemen bencana yang dilakukan.

\section{DAFTAR PUSTAKA}

Ach. Wazir Ws., et al., ed. (1999). Panduan

Penguatan Menejemen Lembaga Swadaya Masyarakat. Jakarta: Sekretariat Bina

Desa dengan dukungan AusAID melalui Indonesia HIV / AIDS and STD Prevention and Care Project

Adi, Isbandi Rukminto. (2007). Perencanaan

Partisiporis Berbasis Aset Komunitas.

Dari Pemikiran Menuju Penerapan. Jakarta: PT Raja Grafindo Persada.
Bintarto, R .(1983). Interaksi Desa-Kota dan Permasalahannya. Yogyakarta: Ghalia Indonesia

BNPB. 2019. Data Informasi Bencana Indonesia (DIBI) (Internet). Badan Nasional Penanggulangan Bencana.

Bungin, HM Burhan. (2007). Penelitian Kualitatif: Komunikasi, Ekonomi, Kebijakan Publik dan Ilmu Sosial Lainnya. Jakarta: Kencana

Carter, Nick. (1991). Disaster management: A Disaster Manager's Handbook. Manila:ABD

Citizen Corps. (2006). Citizen Corps Personal Behavior Change Model for Disaster

Preparedness. Citizen Preparedness

Review. Community Resilience through

Civil Responsibility and Self-Reliance.

Washington : Department of

Homeland Security FEMA.

Conyers,Diana. (1991). Perencanaan Sosial di

Dunia Ketiga. Yogyakarta: Gadjah

Mada University Press

Dian Wijayanto, 2012. Pengantar Manajemen, PT.Gramedia Pustaka Utama, Jakarta

Hidayati, Deny, dkk. 2006. Kajian Kesiapsiagaan Masyarakat Dalam Mengatasi Bencana Gempa Bumi dan Tsunami. Jakarta : LIPI Unesco

Juliantara, Dadang. (2002). Pembaruan Desa: Bertumpu pada Apa yang Terbawa. Yogyakarta: Lapera Pustaka Utama

Mawardi,E. dkk. 2011. Partisipasi Masyarakat Dalam Pengurangan Resiko Bencana Banjir. Surakarta: Pusat Penelitian dan Pengembangan Sumber Daya Air

Miles, Huberman, Saldana. (2014). Qualitative Data Analysis. United State America: SAGE

Nurjanah,dkk. (2012). Manajemen Bencana. Bandung: ALFABETA

Triutomo, S., Widjaja, B. W. \& Amri, M. R. 2007. Pengenalan Karakteristik 
Bencana Dan Upaya Mitigasinya Di Indonesia. Jakarta: Pelaksana Harian Badan Koordinasi Nasional Penanganan Bencana;
Undang- Undang No 24 Tahun 2007 tentang Penanggulangan Bencana 